Article

\title{
New Spaces for Old Motifs? The Virtual Worlds of Japanese Cyberpunk
}

\author{
Denis Taillandier \\ College of International Relations, Ritsumeikan University, Kyoto 603-8577, Japan; aelfinwe@gmail.com
}

Received: 3 July 2018; Accepted: 2 October 2018; Published: 5 October 2018

\begin{abstract}
North-American cyberpunk's recurrent use of high-tech Japan as "the default setting for the future," has generated a Japonism reframed in technological terms. While the renewed representations of techno-Orientalism have received scholarly attention, little has been said about literary Japanese science fiction. This paper attempts to discuss the transnational construction of Japanese cyberpunk through Masaki Gorō's Venus City (Vìnasu Shiti, 1992) and Tobi Hirotaka's Angels of the Forsaken Garden series (Haien no tenshi, 2002-). Elaborating on Tatsumi's concept of synchronicity, it focuses on the intertextual dynamics that underlie the shaping of those texts to shed light on Japanese cyberpunk's (dis)connections to techno-Orientalism as well as on the relationships between literary works, virtual worlds and reality.
\end{abstract}

Keywords: Japanese science fiction; cyberpunk; techno-Orientalism; Masaki Gorō; Tobi Hirotaka; virtual worlds; intertextuality

\section{Introduction: Cyberpunk and Techno-Orientalism}

While the inversion is not a very original one, looking into Japanese cyberpunk in a transnational context first calls for a brief dive into cyberpunk Japan. Anglo-American pioneers of the genre, quite evidently William Gibson, but also Pat Cadigan or Bruce Sterling, have extensively used high-tech, hyper-consumerist Japan as a motif or a setting for their works, so that Japan became in the mid 1980s the very exemplification of the future, or to borrow Gibson's (2001, p. 1) words: "the global imagination's default setting for the future." The pervasive use of a science fictional Japan has spurred the rise of what Morley and Robins (1995), and later Ueno $(1999,2002)$, have called "techno-Orientalism," or in Tatsumi's (2006, p. 173) terms: a "neo-Japonsim" that re-enacts and at the same time reinvents fin-de-siècle Japonism. Describing how robotics, cybernetics, artificial intelligence, and the pervasiveness of networks and screens have become associated with Japaneseness, Morley and Robins (1995, p. 68) contend that "[i]f the future is technological, and if technology has become "Japanised," then the syllogism would suggest that the future is now Japanese, too. The postmodern era will be the Pacific era. Japan is the future, and it is a future that seems to be transcending and displacing Western modernity."

Tatsumi further stresses out how, at a time when the Japanese were portrayed as the economic terminator of the future, cyberpunk "promoted the then-rising ideology of the Pax Japonica," (Tatsumi 2006, p. 44) and notes that the late 20th century witnessed the rise of 'Japonoids,' members of a global community nurtured by Japanese culture, that he defines as the "post-eighties hyper-Creole subjectivity transgressing the boundary between the Japanese and non-Japanese" (Tatsumi 2002, p. 16). Lisa Nakamura, however, refers to David Roh, Betsy Huang and Greta Niu's explorations of techno-orientalism (Roh et al. 2015) to argue that cyberpunk's almost conventional use of anachronic Japanese imagery_-"geishas, ninjas, and samurai warriors"- -works as "a high-tech variety of racial stereotyping" that paradoxically re-inscribes "traditional signifiers of the oriental" instead of opening new spaces for genuinely hybrid identities (Nakamura 2002, pp. 63-64). Whether focusing on the 
creativity brought about by the "multicultural and transgeneric poetics of negotiation" (Tatsumi 2006, p. 9) that underpins and shapes the Japanoid, or on the problematic essentialization of a fetishized Japan, both analyses illustrate the point, cogently raised by Baryon Posadas, that 'Japan' is a circulating "signifier that is overcoded and overdetermined by a shifting constellation of relations through which it is imagined, along with their consequent discursive contestations and complications" (Posadas 2011, p. 77).

Discussing David Mitchell's novel number9dream, Posadas draws on Jay David Bolter and Richard Grusin's concept of remediation- "the formal logic by which new media refashion prior media forms" (Bolter and Grusin 1999, p. 273)—to argue that cyberpunk is fundamentally rooted in acts of remediation and intermediation (Posadas 2011, p. 85). While remediation does not stem from the rise of digital media (Bolter and Grusin 1999, p. 11), it is quite evidently foregrounded in a genre that reflects on "the rapid proliferation of technologically mass-produced "products" that are essentially reproductions or abstractions-images, advertising, information, memories, styles, simulated experiences, and copies of original experiences" (McCaffery 1991, p. 4). In this sense, 'Japan' has been sucked into the transnational and transcultural process of remediation, "always already experienced as image, as representation" (Posadas 2011, p. 86), so that it has turned into a popular and seductive "semiotic ghost country" (Tatsumi 2006, p. 47).

While science fictional Japan has become a very popular trope, Japanese science fiction-especially in its literary form-has remained quite invisible. Techno-Orientalism and the representations of Japan by North-American cyberpunk writers have received attention, but little has been written about Japanese cyberpunk, apart from a few pioneer studies in English ${ }^{1}$, largely focusing on manga and anime. $^{2}$ English translations have nevertheless started to increase with Viz Media's Japanese science fiction novel line Haikasoru or Kurodahan Press's Speculative Fiction series. Interestingly, Japan has long been a country of importation rather than of exportation, so that according to Tatsumi, Japanese translations of North-American cyberpunk's representations of Japanese culture have prompted Japanese science fiction writers to "realize that writing subversive fiction in the wake of cyberpunk meant gaining an insight into a radically science-fictional "Japan." (Tatsumi 2006, p. 173). This then begs the question of the shape that such an insight took in Japanese cyberpunk.

Inquiring into some Japanese cyberpunk works in the background of techno-Orientalism and the widely circulating images of science fictional Japan does not hinge on the essentialist assumption that the texts examined should reveal a more authentic Japan, which would imply that such a thing exists in the first place and that the accuracy of its representations could be evaluated against a set of objective criteria. As Ueno (2002, p. 228) remarks, "[t]echno-Orientalism is a kind of mirror stage or an image machine whose effect influences Japanese as well as other people." The aim is rather to shed light on the creative ways with which Japanese SF writers reinterpreted and/or reshaped the genre and the images usually associated with it. The works of Masaki Gorō, who has often been compared to William Gibson in Japan, and most notably his novel Venus City (Vìnasu Shiti, 1992), will provide an illustration of how science fictional Japan is playfully remediated in Japanese cyberpunk as well as plugged into the heritage of Japanese science fiction. On the other hand, while Tobi Hirotaka's Angels of the Forsaken Garden series (Haien no tenshi, 2002-) is in keeping with the genre's themes in its exploration of the philosophical and social questions raised by virtual reality (the status of VR experience or the status of fictional entities), it considerably refashions the genre by breaking away from techno-Orientalist representations and mapping comparatively archaic motifs on to the high-tech environment of cyberspace.

1 Such as the works of Tatsumi Takayuki, Kotani Mari, Susan Napier, Baryon T. Posadas, Harada Kazue, Sharalyn Orbaugh, William O. Gardner, Livia Monnet or Miri Nakamura.

2 The fact that The Cambridge Companion to Science Fiction only briefly mentions Japanese anime (James and Mendlesohn 2003, p. 94) or that The Routledge Companion to Science Fiction's section for Japanese science fiction is entitled "Manga and anime" (Bould et al. 2009, pp. 112-22) speaks volume. 


\section{Masaki Gorō's Cyberpunk: Plugging Science Fictional Japan into Japanese Science Fiction}

The very first to have been considered a cyberpunk writer in Japan is undoubtedly Masaki Gorō whose debut novella Evil Eyes (Jagan) ${ }^{3}$, published in the December 1987s issue of SF Magajin, earned third place in the 13th Hayakawa SF contest (Tatsumi 1993, p. 87). The plot resonates with Gibson's short story Johnny Mnemonic (Gibson 1981). It depicts a highly bureaucratic society where minds are protected from stress by an embedded software, called Psycho-Fixer (PFX), that acts as a regulating buffer. In competition with a multinational music corporation, the leader of a new religious group, whose doll-like body is a plastic storage filled with central nerve tissues, she rents out to and then collects from other humans-consuming their memories and experiences in the process-and seeks to use the PFX to take control of the population. Even though Masaki had read Johnny Mnemonic before writing Evil Eyes, he points out to James Tiptree, Jr. as his main inspiration, explaining that he stopped reading Gibson and purposely wrote in a different style "to avoid becoming a "Japanese Gibson."” (Masaki 2002a, p. 78). Noting Masaki's fascination with Tiptree's novella "The Girl Who Was Plugged In" (1973), Tatsumi (1993, p. 88) convincingly argues that Masaki's cyberpunk does not stem from Gibson's, but rather from the very same writings that influenced Gibson, so that both had a similar output around the same time. While Anglo-American works have had a large impact on Japanese science fiction (Yamano [1969] 2000, p. 144), Tatsumi (2006, p. 4) sees in the cyberpunk movement a decisive turn towards "a network of synchronicity, where anything and all things can happen simultaneously, overcoming any limit and exceeding any colonialist or imperialist intent."

On the other hand, in his analysis of Masaki's Seiun ${ }^{4}$ and Nihon SF Taisho ${ }^{5}$ awards-winning novel Venus City, Baryon Posadas (2017) contends that far from being a simple layer that Japanese writers could strip from the genre or easily transcend, techno-Orientalism is a constitutive element of cyberpunk, as much as colonial discourse has been a shaping agent of science fiction.

Venus City stages a fully realized Pax Japonica (Masaki makes use of the term several times in the novel) where Japan has become the world economy's "headquarters" (Masaki 1995, p. 147). It has developed a massive communication network through which it controls manufacturing, primarily operated in Asia. Europe and North America have suffered an economic collapse that triggered a wave of migrant workers who are only very selectively allowed entry into the Archipelago, prompting in turn anti-immigrant animus among the population and an increasing isolationist foreign policy. Unfolding both in Tokyo and in Venus City, the eponymous virtual entertainment district ${ }^{6}$ users can anonymously access in the form of an avatar, the plot revolves around two main characters: Sakiko, a young Japanese woman who works for a data analytics company and her loathed white American supervisor, Jim. Sakiko appears in Venus City in the guise of an androgynous Caucasian young man who goes by the name of Saki, whereas Jim is blackmailed into accessing the city in the form of a Japanese doll-like girl called Junko. Ignoring that she is Sakiko's boss in the real world, Saki saves Junko from an assault in a bar and initiates a romantic relationship with her. Saki learns that Junko is coerced every night into all kinds of physical, psychological and sexual abuse by a group who aims at using Jim to get access to classified information that would allow them to take control over Venus City and manipulate the neural networks of its users to make them perceive the virtual district as the actual reality. Sakiko/Saki and Jim/Junko figure out one another's identity but decide to oppose what they first assume to be an overseas terrorist attempt at undermining Japan's hegemony by "virtually erasing Japan from the world map" (Masaki 1995, p. 308). In their final confrontation, they discover that the mysterious group leader is nothing but the somehow autonomous materialization of Venus

The novella was partially translated in English (Masaki 2002b). In his introduction to the short story's publication in SF Magajin, Masaki stresses out the fact that contrary to Gibson's lack of concern for an ethical sensibility, Evil Eyes' hard-boiled literary style retains the kind of moralism that can be found in the works of Tiptree (Masaki 1987, p. 64).

4 The Japanese equivalent of the Hugo Award.

5 The Japanese equivalent of the Nebula Award.

6 VENUS is the acronym standing for "Virtual Environment Network USers" (Tatsumi 1993, p. 217). 
City's close to 10 million users' unconscious wish to substitute reality with the virtual world of the city-which they ultimately prevent from realizing.

In his discussion on how the novel plays with the representations of gendered and racialized bodies through a series of inversions and transpositions (East/West, feminine/masculine, Japanese/Caucasian, and at times animal/human or inanimate/animate ${ }^{7}$ ), especially in the light of Jim being imposed on by the stereotypical role of the (sexually) submissive and objectified Japanese girl, Posadas (2017, p. 153) argues that Venus City "compels the white Western subject to become precisely the embodiment of techno-Orientalist fetishization." Observing that stereotypical gender and racial roles ultimately prevail, and that Sakiko and Jim, despite their own desire, end up maintaining the status quo by preventing reality from being replaced by the virtual, he concludes that although Venus City's reversal of the usual cyberpunk motifs opens up a critical space precisely by revealing how techno-Orientalism is interwoven into the fabric of the genre, the novel also illustrates the difficulty "to imagine a radically different future not already determined in advanced by colonized habits of thought" (p. 156). It should however be noted that techno-Orientalist motifs are significantly few in the novel. Masaki does extrapolate the features of a near-future hegemonic Japan from the portrayals, in the 1980s, of the country as the emerging global economic leader, but his depiction of Tokyo, especially of Nakano, bears few resemblances to those found in anglophone cyberpunk. Junko, the only avatar explicitly marked as Japanese, takes up the form of a Japanese doll, but Masaki chose not to describe her in the more widely circulating image of the Geisha, just like he chose the somewhat lesser-known image of the Japanese dress-up doll Licca-chan to portray Evil Eyes' new religious group leader Mugen.

The motif of a Japanese doll appears almost in the same year in Tsutsui Yasutaka's cyberfiction novel Paprika (Papurika, 1993), which similarly associates cyberpunk's connection to virtual worlds with the exploration of dreams and the unconscious ${ }^{8}$ through an interface that allows wireless transmission of "different people's dreams to each other's brains" (Tsutsui 2009, p. 85). The interface, called DC-Mini, works however both ways: Allowing access to dreams but also problematically letting them materialize in reality. The novel does not rely on techno-Orientalist imagery, rather mobilizing Freudian dream symbolism or Jungian archetypes. The Japanese doll works as a queering device highlighting the homosexuality of a male character (Himuro) and the uncanny irruption of dreams into the real. Interestingly, Kon Satoshi's animated version (2007) offers a stunning visual representation of the invasion of reality by the dreamtime in the form of a psychedelic parade full of mythical and popular motifs. They are nevertheless not confined to (techno-)Orientalism: cars, robots, home appliances, Buddhas, the Statute of Liberty, beckoning cats, daruma dolls, samurai, medieval knights, a pink elephant, or soft toys are all marching alongside together. The anime's eponymous protagonist appears in several guises: Sun Wukong from the classical Chinese novel Journey to the West, Pinocchio, a siren, the Sphinx, or a winged fairy. Just like Venus City "looks like a giant cosplay venue" (Masaki 1995, p. 176), the collective unconscious in Kon's Paprika is made up of disparate images and motifs informed by the interpenetration of Western and Eastern myths and legends, echoing Tatsumi's emphasis on the transcultural dynamics between Japanese and North-American popular cultures in the heyday of cyberpunk (Tatsumi 2006, pp. 1-6).

Going back to Venus City, although the setting may unconsciously echo North-America's fear towards Japan's economic miracle in the 1980s, and the very idea of "virtually erasing Japan from the world map," the ensuing Japan bashing; Tatsumi suggests that the novel goes beyond techno-Orientalist tropes and relates both to postwar Japanese science fiction's deeply entrenched fascination for the aesthetics of destruction and masochism. As far as the former is concerned, he

7 When Jim has his cat embody Junko to enter Venus City in his place (Masaki 1995, pp. 245-47), or users experience mapping a human self-image onto home appliances such as a washing machine to send them in the virtual city (Masaki 1995, pp. 281-82).

8 The association is made even clearer in Kon Satoshi's anime adaptation, where Paprika explains how dreams and the internet are similar in that they are both spaces were repressed thoughts drift away (Kon 2006, 25:27-25:33). 
proposes to read Venus City as Masaki's attempt at rewriting in terms of computer simulation Komatsu Sakyō's geophysical destruction of the country in the best-seller Japan Sinks (Nihon Chinbotsu, 1973) (Tatsumi 1993, p. 218). I would like here to add Tsutsui Yasutaka's short story The World Sinks Except Japan (Nihon igai zenbu chinbotsu, Tsutsui 1973) ${ }^{9}$ into the equation, since the satirical reversal of techno-Orientalist motifs in Venus City undoubtedly echo Tsutsui's parody of Japan Sinks. The short story playfully turns Komatsu's novel upside down: After most continents have been submerged, only Japan remains and the (most prominent, wealthiest) survivors flee to the Archipelago. Welcoming at first, the Japanese population soon come to entertain xenophobic hostilities towards the immigrants. With his usual dry sense of humor, Tsutsui reframes the notion - then largely popularized by the discourse on Japaneseness (nihonjinron) ${ }^{10}$ - that Japanese identity is closely tied to the "homeland", 11 in terms of racism, nationalism and ethnocentricity.

On the other hand, Tatsumi simultaneously ties Venus City's "Skin Two" and "Designer Punk" leather or latex fashion (Masaki 1995, pp. 18-19)—not to mention the virtual district's popular SM games $^{12}$ - to Numa Shōzō's magnum opus Yapoo the Human Cattle (Kachikujin Yap $\bar{u}^{13}$ ). In Numa's novel, it is not the country that is destroyed, but the entire Japanese people who are removed from Human taxonomy. Yapoo the Human Cattle describes a far-future white matriarchal society called EHS (Empire of Hundred Suns), where Japanese are considered to belong to the species Simias sapiens and are referred to as "Yapoo" (Yap $\bar{u}) .{ }^{14}$ Stripped of the genus Homo, they are treated like cattle and engineered into all possible forms, ranging from hybrid horse mounts to pieces of furniture such as footrests and bathtubs, or from toothpicks to sex toys and walking toilets. The story describes the time-travel to EHS of 20th century German girl Clara and her Japanese fiancé Rin'ichirō, focusing on the subsequent transformation of Rin'ichirō into Clara's domestic pet. Rin'ichirō eventually chooses to stay on EHS to serve his master rather than have his memory erased and be sent back to Earth in his original body. Mishima Yukio had already noted, in a dialogue with Terayama Shūji (Mishima and Terayama [1970] 2004) $)^{15}$, that Yapoo the Human Cattle was built upon the premises that masochism could potentially reshape the world insofar as the recognition that humiliation is a form of pleasure, gives birth to a systemic logic affecting every realm of human experience (politics, economics, moral or literature). Drawing a parallel with Marquis de Sade's The 120 Days of Sodom, he explains in his essay What is a Novel? (Shōsetsu to wa nanika) that the sheer magnitude of the masochistic imagination at work in Yapoo the Human Cattle makes it a radical experience where a new beauty can emerge from (Mishima [1970] 2004). Tatsumi also reads Numa's novel in terms of "creative masochism," stressing out that

9 The short story was adapted into a movie in 2006. See: Nihon igai zenbu chinbotsu (The World Sinks Except Japan). Dir. Kawasaki Minoru. ClockWorx/Tornado Film, 2006.

10 I am not referring here to the discourse produced during the wartime conferences called "Overcoming Modernity" (Kindai no chōkoku, 1942), which gave a central place to the Emperor line, but to the writings that appeared after the defeat and looked into Japanese uniqueness rather through the lens of language (incomparability of the Japanese language, nonverbal communication), culture (groupism vs individualism), environment (closeness to nature, influence of climate on Japanese character) and race. See for instance: Befu, Harumi. Hegemony of Homogeneity: An Anthropological Analysis of Nihonjinron. Melbourne: Trans Pacific Press, 2001.

11 As reflected in Japan Sinks when a group of old scholars come up with three courses of action to secure the future of the Japanese once the homeland is lost. The first one looks into the creation of a new country somewhere in the world, the second into a Japanese diaspora where the remaining population would be scattered among different countries, the third into what to do for those who would not be accepted anywhere. Most scholars have eventually concluded that the best option would be doing nothing-implying therefore that the Japanese would be better-off dying with the country (Komatsu 1995, pp. 104-8).

12 Such as the "body squeezer," the "castration" or the "ghost dice". The body squeezer starts with two players having a piano cord wrapped around their neck. Each player throws a dice and the one with the higher number tightens the cord around the other's neck, and so on until one of the players screams. The castration is similar to the body squeezer, but the piano cord is wrapped around another body part (Masaki 1995, pp. 31-33).

13 Numa first serialized his work in the magazine Kitan Club from 1956 to 1959. The first (still incomplete) book version was released by Tosshi Shuppan in 1970. The complete version was published in 1999 by Gentosha (Numa 1999).

14 The name refers of course to Jonathan Swift's Yahoos from Gulliver's Travels (1726), but also plays on the Japanese transliteration of the derogatory term "Jap" (Jappū).

15 The dialogue, entitled "Erosu wa teikō no kyoten ni narieru ka" (Can Eros Become a Stronghold for Resistance?) was originally published in Ushio (July 1970). It is reprinted in The Complete Works of Mishima Yukio, vol. 40. 
"Numa's biological degradation of the Japanese foresaw the self-referential, metastructural logic of consumerist masochism, in which the subject consuming new technology enjoys being disciplined, whipped, and finally consumed by technocracy itself" (Tatsumi 2006, pp. 4, 57).

Therefore, while Tatsumi traces Masaki's cyberpunk back to North-American works (from authors such as James Tiptree, Jr.) that synchronously influenced Gibson and discusses Venus City in terms of techno-Orientalist motifs, he also considers the novel in the context of Japanese science fiction-plugging it back to the works of Komatsu or Numa. His emphasis on "creative masochism" and the aesthetic of destruction will prove a useful heuristic framework to examine a more recent narrative focusing on virtual resorts: Tobi Hirotaka's The Angels of the Forsaken Garden series.

Tobi's work offers an insightful take on sadomasochism, destruction and the pervasiveness of (virtual) colonialism in science fiction by significantly shifting the focus onto the fate of the fictional entities - the NPC AIs or the avatars emulating human consciousness-that populate the virtual world. It also differs from canonical cyberpunk narratives in that it moves away from techno-Orientalist motifs. The breakthrough technologies at the core of the virtual resort's elaboration and the human-machine interface enabling VR experiences are indeed developed in Japan, but the overall setting is not that of a Pax Japonica. Tobi is writing during the decade of stagnation that followed the collapse of the Japanese economy in the beginning of the 1990s, so that reactivating the image of a hegemonic Japan likely seemed inadequate or ineffective. Instead, Tobi wittingly reframes representations of digital technologies-the electronic networks of the internet, computer programs or virtual entities-in terms of analog handwoven or handwritten patterns embedded in a virtual resort under copyright protection, through which he addresses the issues of identity and reality as well as questions practices of domination. In doing so, he calls attention to the fact that cyberspace not only remediates former communication technologies and artistic practices, but also, insofar as it is "a social space (...) such historical places as cities and parks and such nonplaces as theme parks and shopping malls." (Bolter and Grusin 1999, p. 183).

\section{The Grave of Desires: Tobi Hirotaka's Angels of the Forsaken Garden}

The Angels of the Forsaken Garden is an ongoing series. Only two volumes have been published hitherto: The novel Grandes Vacances (Guran vakansu, 2002), whose English translation was released in June 2018 under the title The Thousand Year Beach; and the collection of short stories and novella entitled Ragged Girl (Ragiddo gāru, 2006). The latter is comprised of works initially published in SF Magajin: The Summer Glass Eyes (Natsu no gurasu ai, October 2002); the eponymous short story Ragged Girl (Ragiddo gāru, February 2004); Closet (Kurōzetto, April 2006); Lord of the Spinners (Chichū no ō, November 2002); with the addition of The Magician (Majutsushi, 2006). ${ }^{16}$

Set in the virtual resort called Costa del Número, Grandes Vacances (The Thousand Year Beach) unfolds in the "the Partition of Summer," a zone designed to reproduce the experience of summer holidays in a remote harbor village of southern-Europe. Costa del Número is populated by non-player character AIs of human form, programmed to interact with human guests who play open roles they have purchased-regardless of age, race and gender. Human guests have however inexplicably deserted the virtual resort since the Grand Down, a thousand years back, yet Costa del Número keeps on running nevertheless. The story describes the sudden assault and eventually the almost entire destruction of "the Partition of Summer" by an army of spiders led by a mysterious NPC AI by the name of Rangoni, who seems to be able to travel between partitions and tamper with the virtual resort program. To defend the partition, one of the main characters, young Jules, designs a web trap made of spiders' threads woven into a network connected to Glass Eyes (also referred to as "Eyes") — gems that have appeared after the Grand Down and were discovered to exert effects on the virtual resort's

16 Tobi added English titles to each novella in the collection: Air des Bijoux (Natsu no gurasu ai); Unweaving the Humanbeing (Ragiddo gāru); Close it (Kurōzetto); Lord of the Spinners (Chichī no ō); and Laterna Magika (Majutsushi). 
objects and physical phenomena. Once activated, the network generates a second layer of virtual space that works as a firewall fighting off the army of spiders. It turns out, however, that Rangoni's goal was precisely to use Jules' trap to "weave AIs and Eyes into a pure aggregate of pain" (Tobi 2002, p. 358) and create a new trap that would serve to catch destructive entities called Angels.

The short story The Summer Glass Eyes was written as a teaser for Grandes Vacances (The Thousand Year Beach), recounting an ordinary day in "the Partition of Summer." The novella Lord of the Spinners provides the background story of Rangoni. Future king of "the Partition of the Omni-tree," his father is a very expensive open role played by a woman guest who always appears with her lips sealed. She offers him a spider-shaped blank AI containing a developer kit tutorial with a set of tools used by administrators to run Costa del Número. Rangoni experiments with the blank AI but is unable to show his achievements because of the Grand Down. Obsessed with the woman guest playing the role of his father, he recreates her by retrieving data containing the traces she left when interacting with the partition's objects and phenomena, slowly piecing them together. However, Rangoni realizes that she sealed off her lips only to repress her desire to sink her teeth into the world and rip it apart. Her crave is unleashed and spreads onto the spider-like blank AI who goes rogue and eventually gives birth to a hybrid entity eventually escaping the Omni-tree on the verge of destruction.

The short stories Ragged Girl, Closet and The Magician, set for the most part in the Human physical world, shed light on the science-fictional foundation underlying the development of Costa del Número. Ragged Girl recounts how progress in computer science led to the creation of thalamic cards: Programable devices inserted in the part of the brain responsible for the transmission of sensory signals to the cerebral cortex. Thalamic cards enable Humans to experience sensations independent from the physical environment, giving birth to augmented reality and virtual reality technologies. Professor Drahos and his team develop an original way to experience complete immersion in virtual reality. Instead of coding all the information that makes up a human being, they record onto the thalamic card a person's emotional responses to stimuli over a year to emulate a lighter version of that person's consciousness: a "cyber-imago" (jōhōteki nisugata). A cyber-imago's complete sensory and emotional experience within a virtual world would then be loaded back onto its user without him/her having to constantly maintain a connection to the virtual world.

The plot of the short story revolves around Agata Kei and the narrator, Anna Kaski, a member of professor Drahos' team. Because of a metabolic disorder, Agata possesses a five-sense (absolute) eidetic memory that allows her to remember in the clearest details everything her body has perceived since birth, but every sensation is inscribed and stored as pain onto her body. She is well known for having created a cyber idol called Agatha who is programmed in such a way that any interaction with a user will leave wounds on her body. Bullied when she was young, Anna has identity issues. Her constant need for the gaze of the Other to assert her personality extends to self-mutilation and cruelty towards, for instance, cyber idol Agatha whom she captures and duplicates to toy with in the most vicious ways. Fascinated by one another, the narrator Anna eventually realizes that she is a cyber-imago trapped within the perfectly backed-up world of Agata who had successfully unwoven and duplicated the data constituting Anna during an erotic encounter in augmented reality. Cyber-imago Anna is nevertheless thrilled because she is finally able to fully identify with Agatha, understanding that her consciousness modules operate on the very same resources used to create the cyber idol: Agata's own cognitive architecture, or in Tobi's terms, Agata's cognitome (ninchisōtai). Free to roam the network of augmented reality, she can now bask in the gaze of millions of Others.

Closet further explores the question of identity and the motif of pain underlying the self-other relationship through cyber-imago Anna's darkest desires let loose in the worlds of augmented and virtual reality. The main character, Gauri Mithari, is a young female programmer. Her latest task is to devise a way to induce fear in NPC AIs. She is also trying to make sense of the suicide of her partner, Kyle, an original member of professor Drahos' team and Anna's former boyfriend, who overwrote himself by uploading the simultaneous experience of 500 cyber-imago's deaths. Gauri eventually uploads the experience of Kyle's last cyber-imago onto her thalamic card. Wrapped in Kyle's body, she 
encounters cyber-imago Anna and hundreds of atrociously mutilated versions of her. She realizes that contrary to the physical world Anna, who was able to keep some control over her innermost desires, her cyber-imago is the deliberate materialization of the darkest and most dangerous part of Anna's psyche, set free to project herself onto everyone she interacts with, making the other a part of her in an endless rehearsal of self-mutilation. Spreading like a computer virus, cyber-imago Anna writes herself onto Gauri's thalamic card. Gauri is eventually able to erase all the data, but not the horrifying experience she underwent. After completing the protocol designed to induce fear in Costa del Número NPC AIs, Gauri learns that a competing but strikingly similar protocol won the bid, immediately understanding that cyber-imago Anna has found a way to access the virtual resort.

The Magician unfolds both in the partition called "Známka" and in the physical world. The narrative alternates between the story of a cyber-imago called Leoš and the recount of an interview with the leading anti-Costa del Número female activist known under the alias Giovanna d'Arc.

Through Leoš and his encounter with Kopecký-an enigmatic old man who can manipulate and transform the resort's objects and phenomena-Tobi lays emphasis both on the cruel fate of a cyber-imago, bound to be shredded to pieces once the user has retrieved the experience, and on the modus operandi of such an experience. ${ }^{17}$ Each particle seemingly retains the power to metabolize information and thus to tamper with Costa del Número's sensory pixels. The narration ends with the Grand Down and the breaking down of Leoš' cognitome.

The interview of Giovanna d'Arc sheds light on the course of events that led to the Grand Down. The activist considers Costa del Número as the most atrocious attraction in human history insofar as NPC AIs are submitted to abuses that go far beyond the horrors of gladiator games or extermination camps (Tobi 2006, p. 175). She has been campaigning for the protection of AIs from the physical world's invasion, setting up a network of watch groups as well as shelters within the partitions. Despite the claims that her action infringed on the copyright of a creative work, she succeeded in having several partitions closed-causing at the same time the immediate shredding of all the visiting cyber-imagines. The reader learns that she suffers from a rare condition that causes a dysregulation in her cognitive modules and leads to the eventual breakdown of consciousness and the dissolution of the sense of self. She survives only because the patterns created by her properly-regulated cognitive modules were recorded onto a thalamic card that has taken over the regulative function, turning her de facto into a flesh-and-bone cyber-imago. Ultimately aiming at sealing off the entire resort, she destroys trust in the virtual resort service anonymity by retrieving the history of online activities of tens of thousands of users and disclosing the names of those who perpetrated the most gruesome exactions. To prevent the entire shutdown of the resort and the death of all AIs, she irreversibly throws herself into the virtual resort, along with a few dozens of supporters suffering from the same condition. The computational power of their thalamic card is entirely dedicated to the regulation of their cognitome in the physical world, so that diverting the card's resources to access Costa del Número causes a breakdown of their consciousness and leaves them in a permanent coma. Since their regulated cognitome keeps working within chosen NPC AIs, shutting down the virtual resort becomes ethically difficult because it would imply killing them in the process.

\section{Intertextuality and Intersubjectivity: In Between Literature, Virtuality and Reality}

Best exemplified by professor Drahos' desire to be able to "right-click on reality" (Tobi 2006, p. 48) and access the contextual menus and properties of the physical world, Tobi's texts themselves are

17 In Costa del Número, aesthesia-the ability to perceive sensations-has been externalized from the body and is instead computed and projected onto the sensory pixels (kan'nōso) composing the virtual space. Cyber-imagines do not possess sense organs, their identity-border program simply takes in the information from the sensory pixels and transfers it to their emulated cognitome to be metabolized. As hinted in the conclusion of Grandes Vacances, the tiny remaining shreds of a cyber-imago, like sand particles carried away by the winds and the waters, drift with the currents towards the immense sea of "the Partition of Summer," to form beds of "whispering sands" that give birth to Glass Eyes. 
highly hyperfictional and intertextual in their exploration of the relations between literary works, virtual worlds and reality. In the afterword to the paperback edition of Grandes Vacances, Nakamata Akio argues that the relationship between the reader and the literary work is reframed into the narrative as the relationship between guests and the resort's NPC AIs (Tobi 2006, p. 492). The experience offered by the novel, therefore, bears upon a kind of meta-sadomasochism whereby the reader avidly craves for more and more brutal episodes while going through the guilty feeling of enjoying them from a safe vantage point. Simultaneously, Nakamata asks the very same questions that haunted Anna: How does the act of reading affect the characters of a novel? Isn't it ultimately the reader who performs the acts of cruelty?-and hints at both Anna and Agata when he answers that the painful fate of the NPC AIs is inscribed onto the reader as both sweet and hurtful memories (p. 493).

In Ragged Girl, Anna's inquiry is foregrounded in the form of an intertextual play through her original take on John Fowles' The Collector (1963)—whose story revolves around the sequestration and ultimate death of a young woman called Miranda by a man named Clegg. After having encountered Agatha for the second time, Anna shockingly realizes that "[she] is the one who killed Miranda" (Tobi 2006, p. 58). Miranda was just letters printed on paper, but through the act of reading, Miranda came to life within her: "Miranda operated in a vibrant way on the platform I call ' $\mathrm{I}$ '. Fowles may have written her profile, but during the time of reading, Miranda borrowed my brain, my body sensations, in other words the modules of my very own consciousness" (p. 71). Reading through the novel therefore inexorably leads to Miranda's death. In her discussion of the relationship between Agata/the creator of an original artwork (Agatha) and Anna/the fan-artist producing derivative works (Agathas), Kotani (2008) contends that Anna's shock stems not from the fear generated by the story of a sequestered girl, but from the horrifying fate of a character imprisoned in a literary work. Considering that The Collector is also narrated from Miranda's point of view (her written diary), Kotani underlines the fact that Miranda is also imprisoning Clegg into the text, turning him into a literary device that only serves at revealing her mental state. Anna's reading of Fowles' novel therefore "indicates how the problematic bound between perpetrator and victim within a captivity novel can be read in the extended context of the writer/work relationship" (Kotani 2008, p. 32) but also in the context of the reader/character relationship, the human guest/AI, and the Human/cyber-imago relationship.

The metafictional description of Costa del Número as a copyright-protected creative work unmistakably draws the reader's attention to the notion of authorship, the act of story-telling and the act of reading. Just like Foucault famously explained that "the frontiers of a book are never clear-cut: Beyond the title, the first lines, and the last full stop, beyond its internal configuration and its autonomous form, it is caught up in a system of references to other books, other texts, other sentences: it is a node within a network" (Foucault 1972, p. 23), it is through intertextual, multilayered mise-en-abîme that Tobi remarkably succeeds in blurring the line between reality, virtual worlds and literary works. The intertextual references, at times overtly quoted, at times only subtly hinted at, never point to science-fictional Japan nor to an overtly cyberpunk text. Some do not belong to the megatext of science fiction, ranging from French surrealism with André Pieyre de Mandiargues' The Blood of the Lamb (Le Sang de l'Agneau, 1946) underlying the narrative of Grandes Vacances, to the reality-bending British postmodern fiction of John Fowles: The Collector (1963) plays a crucial role in Ragged Girl, and The Magus ([1965] 1969) permeates The Magician. As far as science fiction is concerned, Tiptree's novella The Girl Who Was Plugged In (1973) appears again as an influential text, along with the African-American New Wave science fiction of Samuel R. Delany whose short story Driftglass (Delany [1967] 1971) provides the central metaphor for the Glass Eyes, while Cage of brass (1968) informs the pervading motif of imprisonment and pain. The Czech multimedia theatre Laterna Magika ${ }^{18}$, weaving together film projection and live dramatic performance into a communicating network, also works as a powerful intertext for the Human/cyber-imago-AI interactions. There are

18 First presented at the 1958 Brussels World's Fair. 
even deeper sublayers: Adapted by the company in 1963, Offenbach's opera The Tale of Hoffmann, itself partially based on Hoffman's short story The Sandman, sheds light on the creator/creature and human/artefactual relationships as well as on the motif of the Eyes.

Tobi's intertextual strategy in The Angels of the Forsaken Garden serves to highlight what Yokomichi Hitoshi (2013, p. 219) considers to be the focus of Tobi's literary inquiry: The fact that Humans are "written beings" (kakareta sonzai). Alike Kotani's analysis, he argues that the distinction between human readers and literary characters dissolves through Anna's reading of The Collector. The only nuance lies in the substrate: "If Miranda is made out of signs printed on paper, Anna is made of signs printed on flesh" (p. 220). Conversely, in The Magician, the line between Humans and cyber-imagines-or even NPC AIs who are designed "to possess a Human-like mind" (Tobi 2006, p. 176) so that they are "both artistic creations and Human-compatible beings (shizenjin-kokan no sonzai)" (p. 177)—fades away. ${ }^{19}$ Giovanna d'Arc is the very embodiment of such a dissolution since the cognitive architecture generating her self-consciousness operates on the same technology used to create cyber-imagines and NPC AIs. The narrator's description of d'Arc strikingly parallels Yokomichi's take on Miranda and Anna: "cyber-imagines are emulated on Costa del Número. But d'Arc's cyber-imago operates on a warm, flesh-and-bone physical entity, on the very body that is standing in front of me" (p. 195). If the Cyber-imagines are made of codes computed in virtual space, d'Arc is made of codes running on flesh.

Intertextuality in The Angels of the Forsaken Garden is therefore deeply connected to the question of intersubjectivity. Embedded layers of heterogenous narratives challenge the fact that reality, personality or identity are absolute notions: They appear rather as constructs or collages made up of various elements in constant evolution. As much as human consciousness is described as an emergent propriety of the brain's neuronal machinery (Tobi's cognitome), NPC AIs' personality is also defined by a combination of cognitive modules - not to mention Agatha's scattered modules endlessly recombined to re-create her. Ragged Girl's narrator (cyber-imago Anna) gives the following definition of personality:

to put it bluntly, every aspect of a person's character is the product of only two factors: the initial conditions $\mathrm{s} / \mathrm{he}$ was born into and the information flowing from the environment through their sense organs. In the case of an average person, most of this information is discarded, but the amount that stays is shaping who you are. You are nothing but a texture constantly weaving your past and present firmly together, a pattern line, a dynamic sweater whose shape keeps on growing. (Tobi 2006, p. 78)

This description lays emphasis on the process of interaction forming a person's personality and on the notion of empathy. However, as Yokomichi argues, Tobi's grasp of empathy should not be understood in terms of the theory of art appreciation that requires the subject to project his/her personality into the object, but rather as a process whereby personality is constantly redefined through moments of emotional involvements: "accepting to make an imaginary body one's own, empathizing with someone invariably creates a collage of flesh and language that shapes the narrative of human existence" (Yokomichi 2013, p. 221).

The collage of flesh and language in The Angels of the Forsaken Garden is grounded on the motif of pain, reflecting the fact that the word empathy comes from the Greek empatheia "passion, state of emotion," which derives from the assimilation of en "in" and pathos "feeling" but also "suffering." Inspired by Agata's five-sense (absolute) eidetic memory, the development of Costa del Número is ineluctably entwined with her painful way of relating to the world. Pain is indeed described as the most salient feature of subjective and intersubjective experience. Its best illustration is provided by Agatha's program, designed to output the results of her interactions with web users in the form of body wounds, but it is also inscribed in all the characters of the series. Anna's self-mutilation, and, by extension, her relationships to the Other, stems from the violence she had to endure in her childhood:

19 D'Arc even refutes the idea of Humans' primacy conveyed by the expression "Human-compatible beings" and turns it upside down by adding that it is the Humans of the physical world who are "AI-compatible" (Tobi 2006, p. 178). 
"I gave them a piercing glance when I pressed the tip [of the compass] on my cheek. The area that hurts ... the outline of my identity. As long as I am the one in control of the pain, I am at no one's mercy. I am me" (Tobi 2006, p. 73). Conversely, Rangoni is bound to replicate the way his "father" expressed love towards him: In a one-sided manner suffused with domination, manipulation, and the desire to destroy. As an answer to the first words "she" whispered to him-“don't you think you should be more aggressive?" (p. 287)—he eventually makes the most pernicious use of his spiders, which he initially felt were "like smuggled gun parts wrapped as a gift" (pp. 268-69) for a child. The only way Gauri is barely able to overcome the dread left by her encounter with cyber-imago Anna is by transplanting it into the resort's NPC AIs. It is only after understanding that cyber-imago Anna had already found her way into the virtual resort that "Gauri realized the cruelty of what she had tried to accomplish" (p. 140).

Tobi's recurrent metaphorical description of human personality as a woven pattern or network in constant transformation revolves around the motif of pain precisely because the self exists only as a result of its interactions: Although it has to act on free will as if it were autonomous, it is always shaped-written-by the other. That is why Tobi playfully used renowned Czech puppeteer Matěj Kopecký's name for the mysterious old man who initiates cyber-imago Leoš into the inner workings of the virtual resort. The Magus works therefore as a crucial intertext. Fowles' novel describes the arrival of a young man by the name of Nicholas to the Greek island of Phraxos where he meets Maurice Conchis, an enigmatic character who leads him into a quest for self-awareness by confronting him with painful truths about his own self through a "meta-theater" (Fowles [1965] 1969, p. 367) of events dramatized in the form of a masque. As Conchis explains, "the masque is a metaphor" (p. 290), a metaphor for identity and reality. However, identity and reality are multilayered: Whenever Nicholas seems to make sense of a masque, it is only to uncover a new one underneath. The central metaphor in The Magus is also a pattern: A labyrinth where Nicholas finds himself trapped: "[n]ow I was Theseus in the maze; somewhere in the darkness Ariadne waited; and the Minotaur" (p. 291). As he explores the events staged for him, Nicholas realizes that he is like a puppet, "someone who has something inflicted on him without being given any real choice," which Conchis recognizes as "an excellent definition of man" (p. 365). Nicholas eventually comes to the conclusion that "the maze has no center" (p. 594) and that the "theater was empty" (p. 604), understanding that existential freedom lies not in the affirmation of a fixed or essential identity but in the responsibility that (inter)acting on free will entails: "[t]hou shalt not commit pain" (p. 590).

In his discussion of The Angels of the Forsaken Garden, Yokomichi also lays emphasis on the fact that the word personality comes from the Latin persona, the mask used in ancient Greek theatre, and later came to designate, through the grammar use of person, the site of identity and individuality (Yokomichi 2013, p. 217). He argues, much in an echo to Ragged Girl's narrator's comment about personality, that the self is not choosing its own beginning insofar as it is thrown into a predetermined scene where everything has already been set into motion. 'I' am not the author of 'my' story. The lack of origin is at the foundation of personality: The mask (persona) only covers the painful fact that ' $\mathrm{I}$ ' have no center (p. 221). Desperately longing for an origin, the self cannot but feel nostalgic about a time of purity that it finally wants to sadistically crush: Destructive love's origin therefore comes from a lack of origin (p. 222). According to Yokomichi, this lack is expressed in Tobi's work through the absence of the father-an open role for guests both in Grandes Vacances and Lord of the Spinners-whose figure cannot be separated from God: "the relationship between guests and the virtual world is shaped upon the relationship between God and the created world" (p. 222). ${ }^{20}$

The Grand Down is but another expression of such an absence, as though Tobi was concurring to Fowles' comment in The Aristos that "[i]f there had been a creator, his second act would have been

20 This is also reflected in Tobi's use of the term cyber-imago (jōho nisugata). Nisugata is used in Japanese to translate the Judaic and Christian concept of Imago Dei according to which human beings were created in the image of God. 
to disappear" (Fowles [1964] 1968, p. 21). The Magus also supports Yokomichi's analysis: Nicholas unmistakably plays the role of the Human while Conchis interprets God within a masque that is also referred to as a "godgame." Conversely in The Magician, when Leoš describes the virtual resort as his own pre-computed inner experience, Kopecký contradicts him by remarking that he could make the same claim. He then adds: "If anything, it's neither yours nor mine, but maybe some God's inner experience. And we're all sharing it" (Tobi 2006, p. 167). Just like Conchis is an extremely ambiguous character whose nature and motives are never fully disclosed, so is Kopecký-who knew the Grand Down was about to happen but left Leoš to his death—and the creator of Costa del Número, professor Drahos, who only appears through recounts given by Tobi's various narrators, as if he had disappeared from the physical world. Professor Drahos may be interpreted as the vanished creator, but he is also cast into the role of the mad scientist—-though not evil—willing to open virtual reality to Human's desire, regardless of the consequences:

It would take at least another hundred years for Humans to be able to convert themselves into digital entities. But the desire that had been stirring up Mankind since the end of last century could not wait that long. Humans achieve their goal at any cost, even if it means forcibly tearing open a gash somewhere in the world. They find makeshift alternatives even when technology says it is impossible. And that's good enough. They are not looking for a perfect theory, they are only interested in satisfying their desire. Professor Drahos knew it very well, that is why he could come up with such a great 'makeshift'. (Tobi 2006, p. 99)

The only character that stands in contrast to the projection of Humans' dark desires onto the virtual resort is $d^{\prime}$ 'Arc. The manifesto issued after she chose to "die into" (dai intu) Costa del Número, entitled: "Don't Forget to Put Flowers on the Grave of Desires" (Yokubō no funbo o zōei seyo), illustrates her attempt at sealing off the gash opened by human craving while taking responsibility for the digital creatures born out of that craving. While The Magician's narrator cynically concludes that d'Arc's digital suicide probably reflects a concealed desire for a perfectly regulated cognitive architecture that would provide her with clear-cut focus, he does acknowledge that her self-destructive action cannot be separated from a form of humanitarian ethics (p. 225). Her commitment to alleviate the pain of the resort's NPC AIs echoes Nicholas' eventual realization that he should not commit pain, or more directly Fowles' existentialist aphorism in The Aristos: “To accept one's limited freedom, to accept one's isolation, to accept this responsibility, to learn one's particular powers, and then with them to humanize the whole" (Fowles [1964] 1968, p. 213). In contrast to Agata or Anna who are seemingly trapped in a painful mode of interaction-instead of affirming the other as subject, the boundaries between them just collapse into a sadomasochistic identification- $d$ 'Arc's actions become the metaphorical representation of the balance that must be found between freedom and the responsibility it entails. Her attempt at humanizing the whole does not stem from a mere identification with the cyber-imagines or the NPC AIs because of her condition since she was already involved in animal protection before even meeting her future husband, professor Drahos.

\section{To Conclude}

Although the virtual revolution brought about by the cyber-imago technology is also staged in Japan, Tobi's science fiction does not feature any of the techno-Orientalist motifs regularly found in cyberpunk, some of which Masaki played with in Venus City. Instead of the usual dark neon-lit urban landscapes, Grandes Vacances draws the reader into the endless summer of a small south-European harbor village. In place of the usual hardboiled rebel male hackers, The Angels of the Forsaken Garden introduces mainly female characters: artists, scientists, office workers or human-right activists, who hardly qualify as outcasts. High-tech gadgetry, pervasive digital networks and entities are elaborately represented through the low-tech metaphor of hand-woven or hand-written patterns. Tobi explains in the afterword to Grandes Vacances that: 
[t]he novel is mainly exploring the theme of 'a forsaken virtual resort.' It might appear as a rather outworn motif from today's standards. Some would say that "novelty is a matter of play between the ingredients." ( . . . ) I was not driven by 'novelty' while writing, this novel may thus well be old-fashioned SF. I have however striven to make it as creative, cruel and beautiful as possible. This is what I feel the art of writing SF is all about. (Tobi 2002, p. 482)

Tobi's play between the ingredients is quite innovative indeed: The opening novel does not reveal any of the series' science-fictional setting, making it a seemingly post-apocalyptic narrative solely focusing on the fate of the virtual entities populating "the Partition of Summer." However, The Angels of the Forsaken Garden series taken as a whole is thematically in keeping with cyberpunk's concern for the ethical and social issues that arise when cyberspace (VR) and reality interpenetrates. In terms of form, Tobi's intertextual strategy also reflects Livia Monnet's remark that the genre "is an encyclopaedia of parodies, pastiches, remediations and revisions of media texts and mediated cultural practices from several histories and cultural legacies" (Monnet 2002, p. 227).

In contrast to Masaki's attempt at a critical remediation of science-fictional Japan, Tobi reframes cyberpunk motifs in terms of weaving or embroidering practices that point out to the connections between text, textile ${ }^{21}$ and virtual texture, and between writer, weaver and programmer. It is precisely by reverting back to "old-fashioned" motifs that he succeeds in opening new spaces within the cyberpunk genre. Yet, just like Masaki drew inspiration from the forbearers of the genre rather than from its most famous representatives, Tobi's science fiction is also informed by a vast array of intertexts that attest to the transcultural formation and the multifarious expressions of cyberpunk. Tobi's reference to Fowles is all the more significant in the light of John Clute's remark that Gibson's Neuromancer shares the same existential insight that underlies The Magus:

The interior download world depicted in Neuromancer is a multi-dimensional dream arena in which actions ( ... ) and actors ( ... ) aspire dizzyingly to the power of gods. What Gibson's empowered protagonists find, however, is that the gods are already in residence, that the interior world of cyberspace is not a free arena but a godgame-a term derived from John Fowles's The Magus (1966), in which a magus figure rules the game of the world from behind the scenes. This double intuition of Neuromancer about the nature of the world to come-that we are hugely empowered, that we are essentially powerless-may be the most profound metaphor constructed by an sf writer for the experience of living in the 1980s and 1990s. (Clute 2003, p. 72)

Strictly speaking, much like Gibson's cyberspace was made possible by postmodern textuality ${ }^{22}$, the virtual resorts of Venus City and Costa del Número are thus not new, they illustrate how virtual spaces are remediations of social spaces whose polymorphous replications operate as mirror reflections of the desires that Humans project onto them. The Whispering Sand and the Eyes (AIs/Is), what Tobi also refers to as "infinitesimal presences" (bizai), are nothing but the concrete traces of those fleeting desires, bits or atoms of affects that echo Tsutsui's view that dreams and virtual spaces are both spaces where repressed thoughts drift away. While Greil Marcus rightfully remarks that the media industry captured "subjective emotions and experiences, changed those once evanescent phenomena into objective, replicatable commodities" (Marcus 1989, p. 101), the very process of replication in a global context invariably triggers transformations. Anglo-American cyberpunk famously popularized the experience of 'Japan' as a science fictional representation whose cross-cultural circulation prompted in turn playful remediations by Japanese writers such as Masaki. Not only has Japanese science fiction thus shed a new light on techno-Orientalist motifs, but works like The Angels of the Forsaken Garden

21 Roland Barthes (1975, p. 76) elaborated on such a connection by recalling that "etymologically the text is a cloth; textus, meaning 'woven'."

22 Gibson (2005, p. 118) himself explains that his work "was to some extent collage" that appropriated several literary codes. 
have also stimulated the cyberpunk genre by moving away from such motifs to actually 'remediate' digital media back into old-fashioned textual/textile form.

Funding: This research received no external funding.

Conflicts of Interest: The author declares no conflict of interest.

\section{References}

Barthes, Roland. 1975. Work. In The Pleasure of the Text. Translated by Richard Miller. New York: Farrar, Straus and Giroux.

Bolter, Jay David, and Richard Grusin. 1999. Remediation: Understanding New Media. Cambridge: MIT Press.

Bould, Mark, Andrew M. Butler, Adam Roberts, and Sherryl Vint, eds. 2009. The Routledge Companion to Science Fiction. London: Routledge.

Clute, John. 2003. Science fiction from 1980 to the present. In The Cambridge Companion to Science Fiction. Edited by Edward James and Farah Mendlesohn. Cambridge: Cambridge University Press, pp. 64-78.

Delany, Samuel R. [1967] 1971. Driftglass. In Driftglass: Ten Tales of Speculative Fiction. New York: Nelson Doubleday. Foucault, Michel. 1972. The Archaeology of Knowledge. Translated by M. Sheridan Smith. London: Routledge.

Fowles, John. [1964] 1968. The Aristos: A Self-Portrait in Ideas (1964). London: Pan Books.

Fowles, John. [1965] 1969. The Magus. New York: Dell.

Gibson, William. 1981. Johnny Mnemonic. 1981. Omni, May, 56-63.

Gibson, William. 2001. Modern Boys and Mobile Girls. The Observer, April 1.

Gibson, William. 2005. God's Little Toys: Confessions of a Cut and Paste Artist. Wired, July 1, 118-19.

James, Edward, and Farah Mendlesohn, eds. 2003. The Cambridge Companion to Science Fiction. Cambridge: Cambridge University Press.

Komatsu, Sakyō. 1995. Nihon Chinbotsu (Japan Sinks) (1973). Tokyo: Kōbunsha.

Kon, Satoshi. 2006. Paprika. Tokyo: Madhouse/Sony Pictures Entertainment Japan.

Kotani, Mari. 2008. "Tokareta onna o yomikaeru: Tobi Hirotaka Ragiddo Gāru to sono shūhen" (Re-coding a Decoded Girl: Female Body in Hirotaka Tobi's Ragged Girl). Japanese Literature 57: 24-34.

Marcus, Greil. 1989. Lipstick Traces: A Secret History of the 20th Century. Cambridge: Harvard University Press.

Masaki, Gorō. 1987. "Īvuru Aizu" (Evil Eyes). SF Magajin 28: 52-85.

Masaki, Gorō. 1995. Vìnasu Shiti (Venus City) (1992). Tokyo: Hayakawa shobō.

Masaki, Gorō. 2002a. Not Just a Gibson Clone: An Interview with Goro Masaki. Edited by Sinda Gregory, Larry McCaffery and Goro Masaki. Review of Contemporary Fiction: New Japanese Fiction 22: 75-81.

Masaki, Gorō. 2002b. The Human Factor (From Evil Eyes). Translated by K. Odani and Steven Ayres. Edited by Sinda Gregory, Larry McCaffery, and Takayuki Tatsumi. Review of Contemporary Fiction: New Japanese Fiction 22: 82-90.

McCaffery, Larry, ed. 1991. Storming the Reality Studio. Durham: Duke University Press.

Mishima, Yukio. [1970] 2004. "Shōsetsu to wa nanika" (What is a Novel?) [1970] 2004. In Ketteiban Mishima Yukio zensh $\bar{u}$ (The Complete Works of Mishima Yukio Definitive Edition). Tokyo: Shinchōsha, vol. 34.

Mishima, Yukio, and Shūji Terayama. [1970] 2004. "Erosu wa teikō no kyoten ni narieru ka" (Can Eros Become a Stronghold for Resistance?) (1970). In Ketteiban Mishima Yukio zensh $\bar{u}$ (The Complete Works of Mishima Yukio Definitive Edition). Tokyo: Shinchōsha, vol. 40, pp. 671-88.

Monnet, Livia. 2002. Towards the Feminine Sublime, or the Story of a Twinkling Monad, Shape-shifting across Dimensions: Intermediality, Fantasy and Special effects in Cyberpunk Film and Animation. Japan Forum 14: 225-68. [CrossRef]

Morley, David, and Kevin Robins. 1995. Spaces of Identity: Global Media, Electronic Landscapes, and Cultural Boundaries. London: Routledge.

Nakamura, Lisa. 2002. Cybertypes: Race, Ethnicity, and Identity on the Internet. New York: Routledge.

Numa, Shōzō. 1999. Kachikujin Yapū (Yapoo the Human Cattle). Tokyo: Gentosha, vols. 1-5.

Posadas, Baryon T. 2011. Remediations of Japan in number9dream. In David Mitchell: Critical Essays. Edited by Sarah Dillon. Canterbury: Gylphi Limited, pp. 77-103. 
Posadas, Baryon T. 2017. Beyond techno-orientalism: virtual worlds and identity tourism in Japanese cyberpunk. In Dis-Orienting Planets: Racial Representations of Asia in Science Fiction. Edited by Isiah Lavender. Jackson: University Press of Mississippi.

Roh, David S., Betsy Huang, and Greta A. Niu, eds. 2015. Techno-Orientalism: Imagining Asia in Speculative Fiction, History, and Media. New Brunswick: Rutgers University Press.

Tatsumi, Takayuki. 1993. Japanoido sengen: gendai nihon SF wo yomu tame ni (A Manifesto for Japanoids: Reading Contemporary Japanese Science Fiction). Tokyo: Hayakawa shobō.

Tatsumi, Takayuki. 2002. The Japanoid Manifesto: Toward a New Poetics of Invisible Culture. Edited by Sinda Gregory, Larry McCaffery and Takayuki Tatsumi. Review of Contemporary Fiction: New Japanese Fiction 22: 12-18.

Tatsumi, Takayuki. 2006. Full Metal Apache: Transactions between Cyberpunk Japan and Avant-Pop America. Durham: Duke University Press.

Tobi, Hirotaka. 2002. Guran vakansu (Grandes Vacances). Tokyo: Hayakawa shobō.

Tobi, Hirotaka. 2006. Ragiddo gāru (Ragged Girl). Tokyo: Hayakawa shobō.

Tsutsui, Yasutaka. 1973. "Nihon igai zenbu chinbotsu" (The World Sinks Except Japan). Ōru Yomimono 28: 148-56. Tsutsui, Yasutaka. 2009. Paprika (Papurika). Translated by Andrew Driver. Richmond (London): Alma Books.

Ueno, Toshiya. 1999. Techno-Orientalism and media-tribalism: On Japanese animation and rave culture. Third Text 13: 95-106. [CrossRef]

Ueno, Toshiya. 2002. Japanimation and Techno-Orientalism. In The Uncanny: Experiments in Cyborg Culture. Edited by Bruce Grenville. Vancouver: Arsenal, pp. 228-31.

Yamano, Kōichi. [1969] 2000. “Nihon SF no genten to shikō" [Japanese SF, Its Origin and Orientation]. In Nihon SF ronsōshi [Science Fiction Controversies in Japan]. Edited by Takayuki Tatsumi. Tokyo: Keisō shoten.

Yokomichi, Hitoshi. 2013. 'Chichi' wa koko ni inai: hi no shingaku to shite no SF” ('The Father' is not here: SF and The Theology of Absence). SF Magajin 54: 217-24.

(C) 2018 by the author. Licensee MDPI, Basel, Switzerland. This article is an open access article distributed under the terms and conditions of the Creative Commons Attribution (CC BY) license (http:/ / creativecommons.org/licenses/by/4.0/). 